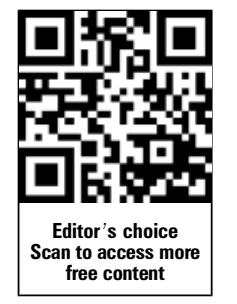

Handling editor Hans WJ Bijlsma

${ }^{1}$ CC12 Department of Medicine, Rheumatology and Clinical Immunology, CharitéUniversity Medicine Berlin, Berlin, Germany

${ }^{2}$ Deutsches

Rheumaforschungszentrum (DRFZ), Charité-University Medicine Berlin, Berlin, Germany

${ }^{3}$ Division of Immunology/ Rheumatology, Stanford University School of Medicine, Palo Alto, California, USA

${ }^{4}$ Department of Pharmacology, Cinvestav, Mexico-City, Mexico

${ }^{5}$ Rheumatology Division, Catholic University of the Sacred Heart, Rome, Italy ${ }^{6}$ Institute of Cellular Medicine, Newcastle University, Newcastle upon Tyne, UK ${ }^{7}$ Musculoskeletal Directorate, Newcastle upon Tyne hospitals NHS Foundation Trust,

Newcastle upon Tyne, UK ${ }^{8}$ Department of Rheumatology, Diakonhjemmet Hospital, Oslo, Norway

${ }^{9}$ Rheumatology Unit, La Paz University Hospital, Madrid, Spain

${ }^{10}$ Herescon GmbH, Hannover, Germany

${ }^{11}$ Department of Medicine III, Division of Rheumatology,

Medical University of Vienna, Vienna, Austria

\section{Correspondence to}

Professor Thomas Dörner, CC12 Department of Medicine, Rheumatology and Clinical Immunology, CharitéUniversity Medicine Berlin, Chariteplatz 1, Berlin 10117, Germany:

thomas.doerner@charite.de

Received 21 September 2012 Revised 23 November 2012 Accepted 2 December 2012 Published Online First 19 December 2012

\section{SLinked}

- http://dx.doi.org/10.1136/ annrheumdis-2012-20294

\title{
The role of biosimilars in the treatment of rheumatic diseases
}

\author{
Thomas Dörner, ${ }^{1,2}$ Vibeke Strand, ${ }^{3}$ Gilberto Castañeda-Hernández, ${ }^{4}$ \\ Gianfranco Ferraccioli, ${ }^{5}$ John D Isaacs, ${ }^{6,7}$ Tore K Kvien, ${ }^{8}$ Emilio Martin-Mola, ${ }^{9}$ \\ Thomas Mittendorf, ${ }^{10}$ Josef S Smolen, ${ }^{11}$ Gerd R Burmester ${ }^{1}$
}

\section{ABSTRACT}

The first biological therapeutics in rheumatology are approaching patent expiration, encouraging development of 'follow-on' versions, known as 'biosimilars'. Biological agents range from simple replacement hormones to complex monoclonal antibodies and soluble receptors: large, intricate proteins with unique tertiary and quaternary structures that are inherently difficult to replicate. Post-translational modifications, such as glycosylation, may occur from changes in cell lines and/or manufacturing processes, resulting in products that are highly similar, but not identical, to approved 'reference' agents, hence, the term 'biosimilar', rather than 'bioidentical'. Even minor modifications in manufacturing processes, which iteratively occur with reference products due to improvements in efficiency, scale up to meet commercial demands or changes in manufacturing sites, may alter biological function and/or

immunogenicity, potentially changing their safety and efficacy profile. As biosimilars are now in randomised controlled trials for treatment of rheumatic diseases, rheumatologists face decisions regarding equipoise and will need to consider their clinical use versus reference products. A clear understanding of the inherent differences between reference antibodies and biosimilars, their clinical implications and the processes governing regulation, approval and clinical use of biosimilars, is paramount. A panel of international experts in the field of rheumatology recently convened to evaluate and discuss these issues.

\section{INTRODUCTION}

The introduction of biological therapeutics for treatment of rheumatic diseases has significantly improved patient outcomes. ${ }^{1}$ With some of these 'reference (originator) products' approaching patent expiration, manufacturers are developing follow-on versions. $^{2}$ Biosimilars may improve access to expensive biological agents; however, concerns have been raised regarding their clinical use. In particular, due to the complexities of manufacturing 'copies' of biological therapeutics, physicians have questioned whether biosimilars will confer identical biological function, efficacy and toxicity to reference products, both in the short and long term. ${ }^{3}{ }^{4}$ These concerns are not without substantiation, since even minor modifications in manufacturing processes, which iteratively occur with reference products, may alter biological functions and/or immunogenicity, potentially changing their safety and efficacy profile ${ }^{5}$ (table 1). Biological agents range from simple replacement hormones to complex monoclonal antibodies (mAbs) and soluble receptor constructs (Cepts)-large, intricate proteins with unique tertiary and quaternary structures that are inherently difficult to replicate. Post-translational modifications, such as glycosylation, may occur from changes in cell lines and/or manufacturing processes, resulting in products that are highly similar, but not identical to approved 'reference' agents, hence the term 'biosimilar', rather than 'bioidentical'. The potential for protein modification to alter biological function is especially true for intricate therapeutic proteins, such as $\mathrm{mAbs}$ and Cepts.

With the expected introduction of biosimilar $\mathrm{mAbs}$ and Cepts, it is important that rheumatologists are familiar with biosimilars, so allowing informed treatment decisions. In order to facilitate this, a panel of international experts convened in Berlin in April 2012 for the roundtable on 'the role of biosimilars in the treatment of rheumatic diseases'. The roundtable provided a forum at which to discuss the potential clinical utility of biosimilars in rheumatology, implications for product efficacy and safety, and their impact on patient care. This article reviews the topics discussed at this meeting, providing physicians with current information in this rapidly evolving field.

\section{RATIONALE FOR THE DEVELOPMENT OF BIOSIMILARS}

In 2012, worldwide sales of the top three selling TNF $\alpha$ inhibitors (TNFi) reached US\$20 billion, ${ }^{13}$ with total annual sales for rheumatic disorders approaching US\$30 billion per year. This amounts to a US\$10 000-30 000 per patient per year financial burden to patients or third-party payers of healthcare. In addition, there is a humanistic burden due to restricted access caused by budget constraints in many countries around the world Thus, there is significant interest in efficacious, lower-cost biosimilars.

\section{DEFINING BIOSIMILAR}

A biosimilar is 'a biotherapeutic product which is similar in terms of quality, safety and efficacy to an already licensed reference biotherapeutic product', with similarity defined as 'the absence of a relevant difference in the parameter of interest'. ${ }^{14}$ Biosimilars should be developed strictly in accordance with comparative procedures used for reference products, as mandated by regulatory authorities, such as the European Medicines 
Table 1 Prior changes in manufacturing processes

\begin{tabular}{|c|c|c|}
\hline Product & Manufacturing change & Result \\
\hline Interferon $\alpha 2 \mathrm{~A}$ & $\begin{array}{l}\text { Biferonics biopartners had master cell bank but could not produce identical product. } \\
\text { Inadequate validation, stability and impurities present formation of aggregates led to } \\
\text { immunogenicity }^{6}\end{array}$ & No approval \\
\hline $\begin{array}{l}\text { Interferon } \beta 1 \mathrm{~A} \text { : } \\
\text { Avonex }\end{array}$ & $\begin{array}{l}\text { Produced by biogen in new mammalian cell line. The resulting product, Avonex, had reduced } \\
\text { immunogenicity compared with that produced in original } \mathrm{CHO} \text { cell line }{ }^{7}\end{array}$ & $\begin{array}{l}\text { Initial production stopped } \\
\text { Subsequent product improved }\end{array}$ \\
\hline rHuEPO: Eprex & $\begin{array}{l}\text { 1998: ortho biotech switched protein stabiliser from human serum albumin to detergent } \\
\text { polysorbate } 80 \text {, with variations in storage and handling; } 2003 \text { introduced prefilled syringe w/ } \\
\text { rubber plunger }{ }^{7-10}\end{array}$ & $\begin{array}{l}\text { Aggregate formation led to formation of anti-EPO Abs } \\
\text { and } 175 \text { cases of pure red cell aplasia 1998-2004 }\end{array}$ \\
\hline $\begin{array}{l}\text { p55TNF-R:lg: } \\
\text { lenercept }\end{array}$ & $\begin{array}{l}\text { Manufacturing processes yielded product with differing glycosylation patterns, resulting in } \\
\text { differences in pharmacokinetics and efficacy }{ }^{9-11}\end{array}$ & Development discontinued \\
\hline $\begin{array}{l}\text { Muromonab aritox: } \\
\text { CD5 plus }\end{array}$ & Switch to manufacturing in dialysis tubing resulted in loss of efficacy ${ }^{9} 10$ & Development discontinued \\
\hline $\begin{array}{l}\text { Primatised } \alpha C D 4: \\
\text { clenoliximab }\end{array}$ & $\begin{array}{l}\text { Working cell bank switched to facilitate manufacturing scale-up. Resulted in CD4 T cell } \\
\text { depletion and loss of efficacy }^{9} 10\end{array}$ & Development discontinued \\
\hline $\begin{array}{l}\text { Darbopoetin } \alpha: \\
\text { Aranesp }\end{array}$ & $\begin{array}{l}\text { Batches produced between } 11 / 2008 \text { and } 4 / 2011 \text { show different sialylation rate, suggesting a } \\
\text { manufacturing change }{ }^{12}\end{array}$ & Iterative manufacturing change \\
\hline Rituximab: Mabthera & $\begin{array}{l}\text { Variation in batches with expiration dates between } 9 / 2007 \text { and } 10 / 2011 \text { suggests a } \\
\text { manufacturing change }{ }^{12}\end{array}$ & Iterative manufacturing change \\
\hline $\begin{array}{l}\text { p75TNF-R:Ig: } \\
\text { etanercept: Enbrel }\end{array}$ & Major differences in glycosylation pattern after 2009 suggest a manufacturing change ${ }^{12}$ & Iterative manufacturing change \\
\hline
\end{tabular}

$\mathrm{CHO}$, Chinese hamster ovary; EPO, erythropoietin.

Agency (EMA) or US Food and Drug Administration (FDA). These stringent processes ensure that no clinically meaningful differences exist between the biosimilar and the reference product in terms of 'safety, purity and potency' (FDA), or 'quality, safety and efficacy' (EMA). ${ }^{15} 16$

Currently, several products labelled as 'biosimilars' are approved for treatment of rheumatoid arthritis (RA) in a number of countries that, at the time of approval, did not have stringent regulatory processes in place to ensure comparability as defined by EMA and FDA (table 2). ${ }^{17}$ While these products apparently meet local regulatory requirements, they should not be considered biosimilars, but rather, 'intended copies'. Physicians must be aware of the distinction between these and 'true' biosimilars that meet EMA/FDA standards, as well as the differences between biosimilars and other 'biological copies' (table 3). ${ }^{18}$

Currently, there are no biosimilar mAbs or Cepts approved by EMA or FDA for treatment of rheumatic diseases, ${ }^{2}$ although randomised controlled trials (RCTs) are complete or on-going (table 4). ${ }^{17}$ Earlier in 2012, the South Korean company, Celltrion, filed for EMA approval of a biosimilar infliximab product, CT-P13. ${ }^{20}$ Two large RCTs-one in 600 RA patients ${ }^{24}$ and another in 250 patients with ankylosing spondylitis

Table 2 'Intended copies' of innovator biologics currently in use for the treatment of rheumatoid arthritis (not subjected to current European Medicines Agency/Food and Drug Administration standards for biosimilarity at the time of approval)

\begin{tabular}{llll}
\hline $\begin{array}{l}\text { Reference } \\
\text { product }\end{array}$ & Manufacturer & $\begin{array}{l}\text { 'Intended } \\
\text { copy' agent }\end{array}$ & $\begin{array}{l}\text { Marketed } \\
\text { locations }\end{array}$ \\
\hline Rituximab & $\begin{array}{l}\text { Dr Reddy's Laboratories } \\
\text { (India) }\end{array}$ & Reditux & $\begin{array}{l}\text { Bolivia, Chile, } \\
\text { India and Peru }\end{array}$ \\
Rituximab & Probiomed (Mexico) & Kikuzubam & $\begin{array}{l}\text { Bolivia, Chile, } \\
\text { Mexico, and Peru }\end{array}$ \\
Etanercept & $\begin{array}{l}\text { Shanghai CP Goujian } \\
\text { Pharmaceutical Co (China) }\end{array}$ & Etanar & Colombia \\
Etanercept & $\begin{array}{l}\text { Shanghai CP Goujian } \\
\text { Pharmaceutical Co (China) }\end{array}$ & Yisaipu & China \\
\hline
\end{tabular}

Adapted by permission from Macmillan Publishers Ltd: (Nature reviews

rheumatology), ${ }^{17}$ copyright (2012).
$(\mathrm{AS})^{25}$-indicate that the efficacy, safety and immunogenicity of CT-P13 are highly similar to infliximab. This biosimilar has recently been approved by the Korean authorities for several indications, including RA and AS. ${ }^{19}$

\section{REFERENCE BIOLOGICALS VERSUS BIOSIMILARS: HOW SIMILAR MUST THEY BE? \\ Reference agents: are they identical to the initial approved product?}

Manufacturing processes of novel biological products are subject to iterative modification, to increase efficiency of production or accommodate manufacturing site changes. ${ }^{12}$ Such changes require extensive analysis of pre- and post-change products (comparability exercise), with subsequent approval by regulatory authorities; EMA/FDA, therefore, have extensive experience in regulating comparability exercises. In the USA,

Table 3 Definitions of therapeutic products

\begin{tabular}{|c|c|c|}
\hline Product & Alternative names & Definition \\
\hline Generic & - & $\begin{array}{l}\text { Exact copy of a } \\
\text { small-molecule drug, } \\
\text { synthesised via chemical } \\
\text { means, with structural and } \\
\text { therapeutic identity to the } \\
\text { reference product }\end{array}$ \\
\hline Biosimilar & $\begin{array}{l}\text { Follow-on biologic (USA); } \\
\text { subsequent entry biologic } \\
\text { (Canada); similar } \\
\text { biotherapeutic product } \\
\text { (WHO) }\end{array}$ & $\begin{array}{l}\text { A biological product that is } \\
\text { highly similar to a reference } \\
\text { product in terms of quality, } \\
\text { safety and efficacy and/or } \\
\text { safety, purity and potency } \\
\text { demonstrated by rigorous } \\
\text { comparability exercises }\end{array}$ \\
\hline $\begin{array}{l}\text { Second-generation } \\
\text { biological }\end{array}$ & Biobetter & $\begin{array}{l}\text { A structurally/functionally } \\
\text { altered biological product } \\
\text { resulting in improved or } \\
\text { different biological activity } \\
\text { from the reference }\end{array}$ \\
\hline Me-too biological & Non-innovator biological & $\begin{array}{l}\text { A biological product } \\
\text { developed with the same } \\
\text { target antigen but without } \\
\text { demonstrated comparability } \\
\text { to the reference product }\end{array}$ \\
\hline
\end{tabular}


Table 4 Agents currently in development with a view to attaining biosimilar status for treatment of rheumatic diseases

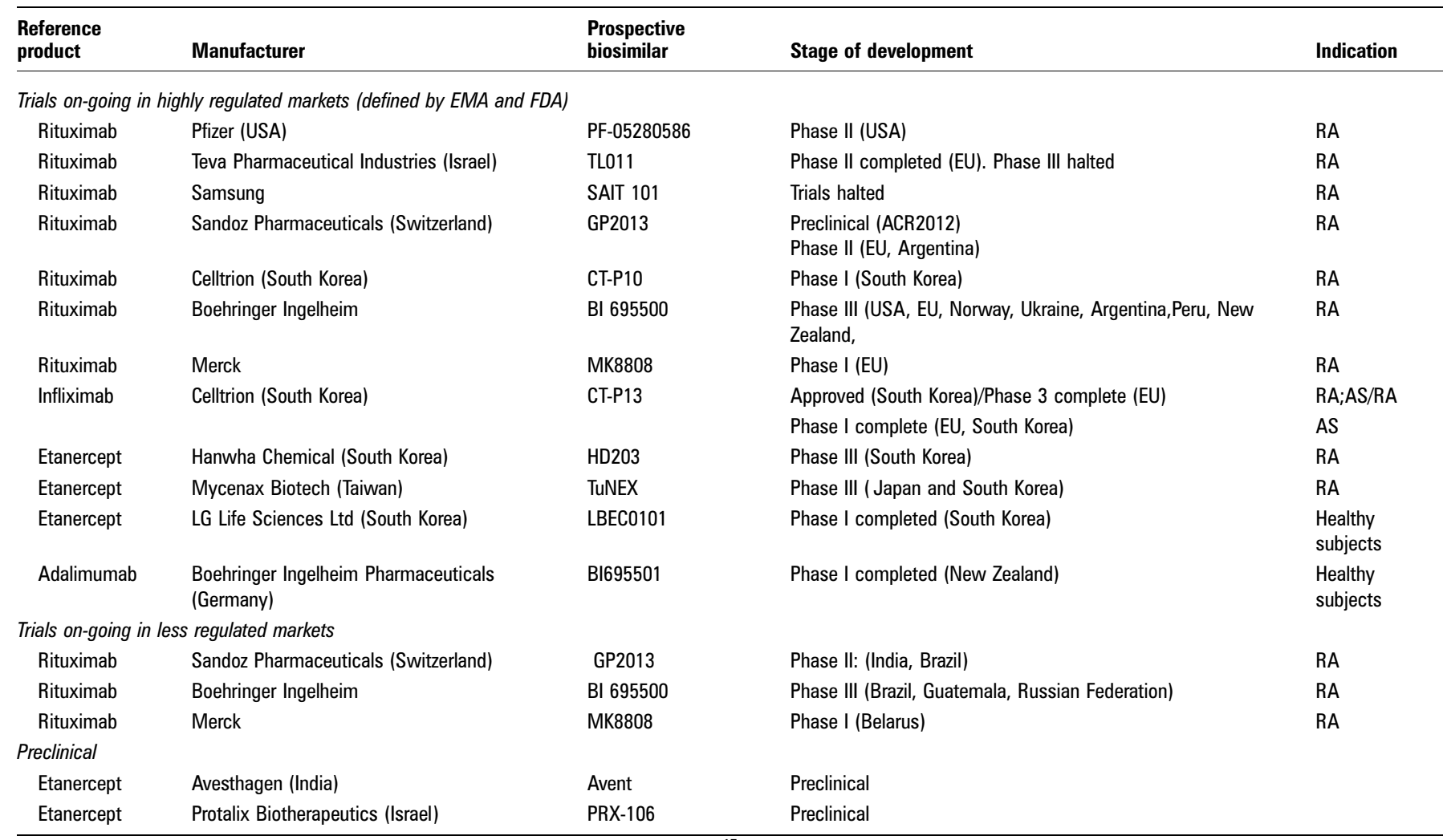

Adapted by permission from Macmillan Publishers Ltd: (Nature reviews rheumatology), ${ }^{17}$ copyright (2012).

Additional information sourced from ${ }^{19-23}$.

AS, ankylosing spondylitis; EMA, European Medicines Agency; FDA, Food and Drug Administration; RA, rheumatoid arthritis.

there is no public regulatory determination of comparability similar to the European Public Assessment Report, ${ }^{26}$ so physicians and patients may never know a manufacturing change has occurred. Clinical testing is, however, mandated when sufficient changes to the reference product occur. Importantly, these alterations are made with a knowledge of the original manufacturing process, which differs from biosimilar development where proprietary manufacturing data are unavailable. EMA and FDA, therefore, stipulate that studies comparing biosimilars to reference products be more extensive. ${ }^{1516}$

\section{Manufacturing and functional implications}

Manufacture of large, complex proteins utilises a living cell line cultured in highly controlled settings. ${ }^{27}$ Subtle changes in protein conformation may result in altered function, insolubility or immunogenicity, ${ }^{5}$ thus, amino acid sequences and higherorder structures must be reproduced. ${ }^{2}$

Biological agents include protein mediators, such as hormones and growth factors, with a molecular weight of $\sim 5000$ $50000 \mathrm{Da}^{28}$ These exhibit well-characterised structural features that can be replicated reliably using recombinant techniques. ${ }^{2}$ By contrast, $\mathrm{mAbs}$ and Cepts are complex molecules, $\sim 150000 \mathrm{Da},{ }^{28}$ which must be folded correctly to maintain conformational integrity. Post-translational modifications (eg, glycosylation, methylation, oxidation, deamidation) may influence tertiary and quaternary structures. ${ }^{29}$ Conformational integrity determines affinity, selectivity, functional activity and immunogenicity of mAbs and Cepts, yet can be inherently difficult to replicate ${ }^{30}$ : glycosylation patterns are not template driven, and are extremely sensitive to minor alterations in manufacturing conditions. ${ }^{5}$ Moreover, deglycosylated peptide motifs represent important sites of B-cell epitopes, thereby providing new or different immunogenic domains. ${ }^{31}$ While these issues have generally led to concerns regarding inferiority of biosimilars compared with reference products, it must be borne in mind that such alterations could potentially lead to superior efficacy and safety. However, according to regulations set forth by EMA and FDA, neither an 'inferior' nor a 'superior' product would qualify as a biosimilar, ${ }^{32} 33$ due to the potential for altered biological activity and/or safety. Biosimilars manufacturers must ensure sufficient analyses are performed to demonstrate a high degree of similarity between reference agents and biosimilars, prior to their entry into equivalence trials.

\section{Importance of conformational structure for biological effect}

Affinity is a key determinant of the pharmacokinetic (PK) and pharmacodynamic (PD) profile of $\mathrm{mAbs}$ and Cepts, potentially impacting their dosing regimen. ${ }^{34}$ Thus, it is important to determine plasma levels and obtain accurate PK and PD data for biosimilars. Antibody binding to target antigen is determined by affinity, but even when affinity is high, concentrations must be adequate to maintain effective binding. The importance of affinity for determining dosing regimens is highlighted by two human TNFi mAbs, adalimumab and golimumab, with similar in vivo half-lives and sizes. Both recognise the same target, albeit different epitopes, yet one is administered every 2 weeks and the other monthly. Higher binding affinity for golimumab appears to be the predominant difference, allowing efficacy to be maintained at lower serum concentrations. ${ }^{34}$ These data highlight the importance of binding affinity for biological efficacy, reflecting the need for close reproduction of conformational structure for biosimilar mAbs and Cepts. 
Immunogenicity

All biological agents are immunogenic because they are non-self; even humanised and 'fully human' mAbs and Cepts can result in measurable immune responses. ${ }^{35}$ Many factors can influence immunogenicity, ${ }^{10}$ such as changes in glycosylation patterns ${ }^{36} 37$ that may expose or hide antigenic components, alter solubility or influence protein degradation. ${ }^{37}$ Importantly, experience has demonstrated that presence of aggregates, impurities or contaminants can provoke unwanted immune responses. ${ }^{7-10} 31$ Thus, alterations in manufacturing processes/storage conditions may result in altered immunogenicity of biosimilars compared with reference products.

The effects of antibiological antibodies include reduction in serum levels, adverse events and formation of neutralising antibodies. ${ }^{10}$ Anti-infliximab antibodies have been associated with infusion reactions in patients with Crohn's disease, ${ }^{38}$ while antiadalimumab antibodies may heighten the risk of rare thromboembolic events in patients with RA and psoriatic arthritis. ${ }^{39}$ Postmarketing surveillance of TNFi mAbs has identified a potential link between antibiological antibodies and treatment-related vasculitis, albeit very rare events. ${ }^{40} 41$ It is therefore important to implement clinical trials of sufficient size and duration to determine the safety of biosimilars and postmarketing surveillance to identify rare adverse events. This is also important for reference products that undergo iterative manufacturing process alterations resulting in consequences if significant changes occur.

Most commonly, immunogenicity contributes to loss of clinical efficacy, that is, tachyphylaxis. Loss of clinical responses to TNFi occur over time, ${ }^{38} 42$ and have been associated with the presence of antibiological antibodies in some patients. This is more common in those with Crohn's disease, where intermittent administration is more frequent and background medication less commonly utilised when compared with RA. ${ }^{43} 44$

Route of administration and host-related factors also influence immunogenicity. ${ }^{10}$ Patients with autoimmune diseases more commonly develop antibiological antibodies, ${ }^{10}$ as well as naturally occurring anticytokine autoantibodies. Consideration of separate clinical trials for biosimilars in different therapeutic indications is therefore important.

\section{Fc effector function}

Activity of mAbs and Cepts depends not only upon interactions with target antigen, but also Fc receptor (Fc $\gamma R$ ) function. ${ }^{46}$ Mutations of just one amino acid are sufficient to impair Fc interactions, thereby altering complement activation and/or antibody-dependent cytotoxicity, and reducing the efficacy of therapeutic mAbs. ${ }^{46}$ For example, two anti-CD20 $\mathrm{mAbs}$, ofatumumab and rituximab, display different levels of $\mathrm{B}$ cell depletion, potentially due to altered fucosylation patterns. Due to constraints in conformational changes, etanercept exhibits reduced complement binding compared with infliximab and adalimumab. ${ }^{47}$ Efficacy of mAbs can also be affected by individual patient characteristics: in patients with $\mathrm{RA}^{48}$ and psoriatic arthritis, ${ }^{49} \mathrm{Fc} \gamma \mathrm{R}$ polymorphisms result in different responses to TNFi. Biosimilars must, therefore, demonstrate highly similar efficacy and safety to the reference product in well-designed RCTs.

\section{Properties of biosimilars: how similar is similar enough?}

The key question for biosimilars is not whether differences exist compared with the reference, but whether differences are clinically relevant. Microheterogeneity is a feature of batch-to-batch variability for any biological agent, ${ }^{12}$ and sometimes major changes occur with alterations to manufacturing processes; the degree of variability is assessed with quality control of each batch. As manufacturing processes for biologicals become more efficient, batch sizes increase, and only one or two batches may account for the entire use of a reference product in the European Union (EU) or USA over a 1-year period. For biosimilars, it is necessary to establish 'acceptable variation' parameters for comparability with the reference product. If comparisons are to a single batch, then these parameters will be more narrow than the batch-to-batch variation of the reference product. ${ }^{50}$

Given their inherent complexity, biosimilar mAbs and Cepts cannot be absolutely identical to the reference. However, certain fundamental features must be retained (table 5). Even sophisticated comparability testing, in vitro assays and animal studies cannot fully predict the biological and clinical activity of a therapeutic $\mathrm{mAb}{ }^{10}$; the only way to sufficiently assess the efficacy and safety of biosimilars is via RCTs in patients with the disease in question. Concerns surrounding the immunogenicity of biological products have previously been compounded by the limited clinical relevance of standardised assays for antibiological antibodies. ${ }^{10}$ However, the emergence of biosimilars has encouraged development of more robust assays that can detect antibodies in the presence of higher circulating levels of mAbs and Cepts, ${ }^{51}$ which can be used in clinical settings.

\section{THE BIOSIMILAR APPROVAL PROCESS AND CLINICAL CONSIDERATIONS}

EMA led the way in developing a pathway for the approval of biosimilar agents in the EU. ${ }^{15} 32{ }^{52}$ Guidance for the approval of biosimilar agents containing $\mathrm{mAbs}$ was issued in May $2012 .{ }^{53}$ In February 2012, FDA released a three-part draft guidance document outlining the approval pathway for biosimilars in the USA ${ }^{16} 3354$ based on the Biologics Price Competition and Innovation Act (BPCIA) passed on 23 March 2010. ${ }^{55}$

\section{The aim of the clinical development programme}

Acceptance of biosimilars among rheumatologists requires an understanding of the regulatory processes governing their approval. For EMA and FDA, a biosimilar clinical development programme must demonstrate equivalence to a reference product already licensed (and manufactured) for use in Europe or the USA, respectively. The aim is distinct from a de novo approval pathway, where establishing safety and efficacy, per se, is the ultimate goal. A demonstration of biosimilarity will establish patient benefit and safety.

\section{Demonstrating biosimilarity}

Demonstrating biosimilarity differs significantly from generic drug approval, where only PK equivalence must be shown. Extensive, non-clinical physiochemical and biological characterisation is required to address structural, functional and immunogenicity concerns, prior to efficacy and safety trials. Thus, the chemistry, manufacturing and controls portion of a biosimilar application is likely larger and more detailed than that of the reference product. The non-clinical portfolio must provide comparability data that are almost superimposable with the reference, through the use of 'fingerprint'-like analyses to detect differences between highly complex mAbs. ${ }^{50}$

Clinical data requirements differ in the EU and the USA (table 5). However, the same basic principle is followed: equivalent, as opposed to superior safety and efficacy must be demonstrated. Both EMA and FDA require RCTs to be of sufficient 
Table 5 Essential characteristics and clinical study requirements for the approval of biosimilar products in the EU and USA

\begin{tabular}{|c|c|c|}
\hline Characteristic & \multicolumn{2}{|l|}{ FDA and EMA requirements } \\
\hline Primary amino acid sequence & \multicolumn{2}{|c|}{ One amino acid change respective to the innovator will deny biosimilarity } \\
\hline Potency & \multicolumn{2}{|l|}{ Must match the reference product } \\
\hline Route of administration & \multicolumn{2}{|c|}{ Must be the same as the reference product, although the administration device may be different } \\
\hline $\begin{array}{l}\text { Higher-order structures, post-translational } \\
\text { modifications and other potential variants }\end{array}$ & \multicolumn{2}{|c|}{$\begin{array}{l}\text { Must be as similar as possible to the reference product, with adequate analyses to demonstrate that any differences do } \\
\text { not impact upon clinical efficacy, safety or immunogenicity }\end{array}$} \\
\hline Clinical study parameter & FDA & EMA \\
\hline Pharmacokinetic studies & Comparative human studies & Single dose, comparative human studies \\
\hline Pharmacodynamic studies & $\begin{array}{l}\text { Comparative human studies, where clinically } \\
\text { relevant measures are available }\end{array}$ & $\begin{array}{l}\text { Combine with PK studies where a clinically relevant PD endpoint is } \\
\text { available. Otherwise non-clinical evaluation required }\end{array}$ \\
\hline Efficacy & $\begin{array}{l}\text { At least one, adequately powered } \\
\text { equivalence* trial }\end{array}$ & $\begin{array}{l}\text { Highly sensitive, dose-comparative PD studies may be sufficient. } \\
\text { Otherwise, at least one, adequately powered equivalence trial }\end{array}$ \\
\hline Safety & $\begin{array}{l}\text { At least one, adequately powered } \\
\text { equivalence trial }\end{array}$ & At least one, adequately powered equivalence trial \\
\hline Immunogenicity & $\begin{array}{l}\text { At least two comparative trials, one pre- and } \\
\text { one postmarketing }\end{array}$ & Must be assessed during the safety trial \\
\hline
\end{tabular}

*Differences in the specified parameters and the $95 \% \mathrm{Cl}$ fall within a predetermined equivalence margin, demonstrating that the biosimilar is both 'non-inferior' and 'non-superior' to the reference product.

EMA, European Medicines Agency; FDA, Food and Drug Administration; PD, pharmacodynamic; PK, pharmacokinetic.

size to establish clinical equivalence; however, rare adverse events and long-term efficacy and safety will be assessed through postmarketing surveillance. Thus, as for reference agents, stringent postapproval pharmacovigilance is paramount.

\section{Extrapolation of clinical indications}

Extrapolation of clinical data permits the approval of a biosimilar for a therapeutic indication in which it has not been clinically evaluated, but for which the reference agent is approved. Both EMA and FDA advocate extrapolation, and have outlined measures to address the concerns associated with it (table 6). The rationale is that if biosimilarity is confirmed using EMA/ FDA criteria, it is scientifically reasonable to assume that the biosimilar will behave in a similar manner to the reference in all clinical scenarios. Indeed, Celltrion's TNFi demonstrated equivalent efficacy to infliximab in RA and $\mathrm{AS}^{24} 25$

However, extrapolation may be less appropriate when the two therapeutic indications involve distinctly different practices and disease biology, ${ }^{56}$ and will therefore be considered by
EMA/FDA 'case-by-case' (table 6). While extrapolation criteria have been designed to mitigate many concerns, extrapolation should be clearly indicated in the product label.

\section{Postapproval pharmacovigilance}

Both EMA and FDA emphasise the need for postmarket surveillance for biosimilars. Adverse event reports should contain as much information as possible, identifying the specific agent, type of event and its occurrence. ${ }^{57}$ This will be particularly important for documenting events occurring as a result of switching between reference and biosimilar agents. The ability to differentiate between reference and biosimilar agents will also be paramount, raising issues regarding naming of biosimilars.

\section{Automatic substitution and naming}

Automatic substitution would enable pharmacists to dispense a biosimilar, instead of the reference agent, without prior consent of the prescribing physician. EMA does not have the authority to designate a biosimilar as automatically substitutable, ${ }^{2}$

Table 6 EMA and FDA response to concerns regarding extrapolation of clinical data

\begin{tabular}{|c|c|c|c|}
\hline Concern & EMA & FDA & Points to consider \\
\hline $\begin{array}{l}\text { MOA may be distinct in each } \\
\text { therapeutic indication }\end{array}$ & \multicolumn{2}{|c|}{$\begin{array}{l}\text { Extrapolation will be considered on a case-by-case basis. Where the MOA differs } \\
\text { between indications or are not fully understood, separate clinical trials are likely } \\
\text { to be necessary }\end{array}$} & $\begin{array}{l}\text { For instance, separate trials are likely to be necessary for } \\
\text { rheumatology versus oncology. }\end{array}$ \\
\hline $\begin{array}{l}\text { For a given MOA, several } \\
\text { mechanisms may exist }\end{array}$ & \multicolumn{2}{|c|}{$\begin{array}{l}\text { Almost superimposable biological data must be provided, covering all functional } \\
\text { aspects of the agent, even if not considered clinically relevant. Where MOA are } \\
\text { not fully understood, separate clinical trials are likely to be necessary }\end{array}$} & \\
\hline $\begin{array}{l}\text { Risk of undertreating patients/ } \\
\text { varied safety profiles in } \\
\text { different patient groups }\end{array}$ & \multicolumn{2}{|c|}{$\begin{array}{l}\text { Data should be produced using a patient population and clinical endpoint most } \\
\text { sensitive to detect clinically meaningful differences in efficacy and safety }\end{array}$} & $\begin{array}{l}\text { Disease activity at baseline represents an important } \\
\text { variable related to outcome measures in RA-likely to } \\
\text { have limited impact on a direct comparison between } \\
\text { biosimilar and reference products when sensitive } \\
\text { measures are used, but needs consideration when } \\
\text { efficacy is compared with reference product trials. }\end{array}$ \\
\hline $\begin{array}{l}\text { Individual patient } \\
\text { characteristics may influence } \\
\text { the response }\end{array}$ & $\begin{array}{l}\text { Homogeneous population should be } \\
\text { used-differences in response can then } \\
\text { be attributed to the biosimilar. }\end{array}$ & $\begin{array}{l}\text { Careful consideration must be given to } \\
\text { comorbidities/concomitant } \\
\text { medications and intersubject } \\
\text { variability. }\end{array}$ & $\begin{array}{l}\text { EMA approach-it will be difficult to identify a } \\
\text { homogeneous population for a heterogeneous condition } \\
\text { such as RA }\end{array}$ \\
\hline
\end{tabular}


although each country will follow its own national guidelines. In the USA, two approval pathways are expected, one for biosimilars which are 'highly similar' to the reference, and another, more rigorous pathway for 'interchangeable' products that are eligible for automatic substitution. ${ }^{54}$ BPCIA states: 'to meet the higher standard of 'interchangeability', an applicant must provide sufficient information to demonstrate biosimilarity, and also to demonstrate that the biological product can be expected to produce the same clinical result as the reference product in any given patient and, if the biological product is administered more than once to an individual, the risk in terms of safety or diminished efficacy of alternating or switching between the use of the biological product and the reference product is not greater than the risk of using the reference product without such alternation or switch. ${ }^{55}$ The exact criteria allowing designation of a product as 'interchangeable' are still under consideration by FDA.

Substitution may complicate effective pharmacovigilance, as repetitive switching of agents may subvert the ability to attribute adverse events to the appropriate agent, and could force withdrawal of treatment. Therefore, it will be important that a name or feature can distinguish those biosimilars with automatic substitution status from the reference product. Pharmacists should be aware of their own national guidelines regarding automatic substitution, and understand that retention of international non-proprietary (generic) names (INN) is not a signal for automatic substitution.

Nomenclature must allow physicians to identify biosimilar products and communicate prescriptions accurately with pharmacists. Ascribing new INNs to biosimilars may cause confusion among healthcare professionals, while new brand names may not be sufficient due to possible exclusion from prescribing information. Additional markers, which clearly discriminate between reference, biosimilar and interchangeable agents, may be required.

\section{WILL BIOSIMILARS BE SUCCESSFUL?}

The role of biosimilars in rheumatic diseases will be determined by the confidence placed in them by rheumatologists; stringent regulatory approval processes are designed to provide this. To date, the uptake of biosimilars in European and US markets has been limited, ${ }^{2} 58$ which may be explained by the relatively modest cost savings of $15-30 \%$ compared with $\sim 80-90 \%$ afforded by generic drugs. ${ }^{58}{ }^{59}$ It is currently difficult to predict cost savings for biosimilar mAbs and Cepts in highly regulated markets. In other regions, economic pressures and significant cost savings have forced the use of 'intended copies' despite the concern that their safety and efficacy have not been adequately characterised. ${ }^{17}$ Regarding 'true' $\mathrm{mAbs}$ and Cepts, several 'reference product' manufacturers are currently engaged in biosimilar development and production, ${ }^{21} 22$ 60-63 indicating that this field is of significant interest.

\section{SUMMIARY AND CONCLUSIONS}

It is important that rheumatologists distinguish between biological 'intended copies' and biosimilars. To attain biosimilar status, an agent must undergo the required comparability qualification in accordance with scientific principles endorsed by authorities, such as EMA or FDA. Despite these stringent approval processes, significant savings in costs are expected. Once available, physicians prescribing them must be aware of any developments concerning biosimilars, and be vigilant in their use.
Acknowledgements We would like to thank Dr Christian Schneider for his contribution to the 'Roundtable on Biosimilars for the Treatment of Rheumatic Diseases' discussions in Berlin, Germany, 25 April 2012. Editorial assistance was provided by Ruth Coughlan, International Medical Press. Grant support was provided by F. Hoffmann-La Roche Ltd and Charite Universitätsmedisin Berlin.

Contributors All authors contributed to the drafting, review and final approval of the manuscript. In addition TD, VS, GC-H, GF, TKK, EM-M, TM and GRB contributed to discussions at the roundtable meeting.

Funding The Roundtable on Biosimilars for the treatment of rheumatic diseases (Berlin, Germany, 25 April 2012) was made possible by an unrestricted educational grant from F. Hoffmann-La Roche Ltd and funding support from Charite Universitätsmedisin Berlin. The sponsors had no involvement in the agenda or development of the manuscript, which were developed by the authors alone. Authors and roundtable participants contributed significantly to discussions and interpretation during the roundtable meeting and preparation of the manuscript.

Competing interests TD has received clinical study support and/or consultancy fees from Teva Pharmaceuticals, Roche, Baxter, Imunomedics Inc, Sanofi, Takeda and UCB Pharma. VS has received consultancy fees from Abbott, Amgen, AstraZeneca, BMS, Genentech/Roche, GSK, Janssen, Lilly, Merck Serono, Novartis, Pfizer, Regeneron, Sanofi and UCB Pharma. GC-H has nothing to declare. GF has nothing to declare. JI has received consultancy fees from Roche and Pfizer, and lecture fees and grant support from Roche Pfizer and Abbott. TK has received consultancy fees from Abbott, BMS, MSD/Schering Plough, Pfizer/Wyeth, Roche, UCB Pharma and Fourteen22, grant support from Abbott, BMS, MSD/Schering Plough, Pfizer/Wyeth, Roche, UCB Pharma and lecture fees from Abbott, Astra Zeneca MSD/Schering Plough, Pfizer/Wyeth, Roche and UCB. EMM has received board membership and consultancy fees from Pfizer, Roche, UCB Pharm and Abbott, lecture fees from Pfizer and Roche and grant support from Pfizer. TM's institution has received consultancy fees from Abbott, Pfizer and UCB Pharma. JS has received consultancy fees from Abbott, BMS, Celgene, Centocor, Glaxo, Medimmune, MSD, Pfizer, Roche and UCB, grant support from Abbott, BMS, Centocor, MSD, Pfizer, Roche and UCB, lecture fees from Abbott, BMS, Janssen, MSD, Novartis-Sandoz, Pfizer, Roche, UCB and royalties from Elsevier. GB has received board membership fees, consultancy fees, lecture fees and grant support from Abbott, BMS, MSD, Pfizer, Roche and USB Pharma. The Roundtable on Biosimilars for the treatment of rheumatic diseases (Berlin, Germany, 25 April 2012) was made possible by an unrestricted educational grant from

F. Hoffmann-La Roche Ltd. The sponsor had no involvement in the roundtable agenda or development of the manuscript.

Provenance and peer review Not commissioned; externally peer reviewed.

Correction notice This article has been corrected since it was published Online First. The handling editor has been corrected.

\section{REFERENCES}

1. Agarwal SK. Core management principles in rheumatoid arthritis to help guide managed care professionals. J Manag Care Pharm 2011;17:S03-8.

2. Dranitsaris G, Amir E, Dorward K. Biosimilars of biological drug therapies: regulatory, clinical and commercial considerations. Drugs 2011;71:1527-36.

3. Owens DR, Landgraf W, Schmidt $A$, et al. The emergence of biosimilar insulin preparations-a cause for concern? Diabetes Technol Ther 2012;14:989-96.

4. Roger SD, Mikhail A. Biosimilars: opportunity or cause for concern? J Pharm Pharm Sci 2007; 10:405-10.

5. Revers L, Furczon E. An introduction to biologics and biosimilars. Part II: subsequent entry biosimilars: biosame or biodifferent? Can Pharm J 2010;143:184-91.

6. CHMP Assessment Report: Biferonix Interferon b1A Procedure No.EMEA/H/C/ 000901. July 2009. http://www.emea.europa.eu/docs/en GB/document library/ Application_withdrawal_assessment_report/2010/01/WC500091394.pdf laccessed 12 Aug 2012).

7. Woodcock J, Griffin J, Behrman R, et al. The FDA's assessment of follow-on protein products: a historical perspective. Nat Rev Drug Discov 2007;6:437-42

8. Eckardt KU, Casadevall N. Pure red-cell aplasia due to anti-erythropoietin antibodies 3. Nephrol Dial Transplant 2003;18:865-9.

9. Strand V, Smith J. Introduction of a biologic agent into the clinic. In: Weinblatt ME, Louie JS, vanVollenhoven RF Targeted treatment of the rheumatic diseases. Philia: Saunders, 2010: 451-62.

10. Strand V, Kimberly R, Isaacs JD. Biologic therapies in rheumatology: lessons learned, future directions. Nat Rev Drug Discov 2007;6:75-92.

11. Keck R, Nayak N, Lerner $L$, et al. Characterization of a complex glycoprotein whose variable metabolic clearance in humans is dependent on terminal $\mathrm{N}$-acetylglucosamine content. Biologicals 2008;36:49-60.

12. Schiestl $\mathbf{M}$, Stangler T, Torella $\mathrm{C}$, et al. Acceptable changes in quality attributes of glycosylated biopharmaceuticals. Nat Biotechnol 2011;29:310-12.

13. Huggett B, Hodgson J, Lahteenmaki R. Public biotech 2009-the numbers. Nat Biotechnol 2010:28:793-9. 
14. World Health Organization. Expert committee on biological standardization. Geneva, 19 to 23 October 2009. Guidelines on evaluation of similar biotherapeutic products (SBPs). http://www.who.int/biologicals/areas/biological therapeutics/ BIOTHERAPEUTICS FOR WEB 22APRIL2010.pdf (accessed 10 Sep 2012).

15. European Medicines Ägency. Guideline on similar biological medicinal products containing biotechnology-derived proteins as active substance: quality issues. 2006 http://www.ema.europa.eu/docs/en_GB/document_library/Scientific_guideline/2009/ 09/WC500003953.pdf (accessed 11 Apr 2012).

16. US Food and Drug Administration. Quality considerations in demonstrating biosimilarity to a reference product: draft guidance February 2012. http://www.fda. gov/downloads/Drugs/GuidanceComplianceRegulatoryInformation/Guidances/ UCM291134.pdf (accessed 4 Apr 2012).

17. Scheinberg MA, Kay J. The advent of biosimilar therapies in rheumatology-"0 Brave New World". Nat Rev Rheumatol 2012;8:430-6.

18. Weise M, Bielsky MC, De Smet K, et al. Biosimilars-why terminology matters. Nat Biotechnol 2011:29:690-3.

19. GaBI online. Biosimilar monoclonal antibody approved in Korea. Posted on 03/08/ 2012. http://www.gabionline.net/Biosimilars/News/

Biosimilar-monoclonal-antibody-approved-in-Korea (accessed 4 Aug 2012).

20. Biosimilar news. Biosimilar Remicade under review in EU. Posted April 132012. http://www.biosimilarnews.com/biosimilar-remicade-under-review-in-eu laccessed 10 Aug 2012).

21. ClinicalTrials.gov. A Study of the Pharmacokinetics and Safety of MK-8808 (MK-8808-002 AM3 EXT 1). http://www.clinicaltrials.gov/ct2/show/NCT01390441? term $=$ MK-8808qrank $=2$ (accessed 8 Nov 2012).

22. GaBI online. Teva halts phase III biosimilar rituximab trial Posted 12/10/2012. http:// www.gabionline.net/layout/set/print/content/view/full/2162 (accessed 8 Nov 2012)

23. ClinicalTrials.gov. Efficacy, Pharmacokinetics, and Safety of BI 695500 in Patients With Rheumatoid Arthritis. http://www.clinicaltrials.gov/ct2/show/NCT01682512? term $=\mathrm{BI}+695500$ grank $=1$ (accessed 8 Nov 2012).

24. Yoo D, Miranda P, Piotrowski M, et al. A randomized, double-blind, phase 3 study demonstrates clinical equivalence of CT-P13 to infliximab when co-administered with methotrexate in patients with active rheumatoid arthritis [abstract]. Ann Rheum Dis 2012;71(Suppl3):359.

25. Park W, Hrycaj P, Kovalenko V, et al. A randomized, double-blind, phase 1 study demonstrates equivalence in pharmacokinetics, safety, and efficacy of CT-P13 and infliximab in patients with ankylosing spondylitis [abstract]. Ann Rheum Dis 2012;71 (Suppl3):111.

26. European Public Assessment Report (EPAR) for Aranesp. http://www.ema.europa.eu/ ema/index.jsp?curl=pages/medicines/human/medicines/000332/ human med 000651.jspgmurl=menus/medicines/medicines. jsp\&mid $=$ WC 0 b01ac058001d125\&jsenabled=true (accessed 31 Aug 2012)

27. Schellekens H. Biosimilar therapeutics-what do we need to consider? NDT Plus 2009;2:i27-36

28. Revers L, Furczon E. An introduction to biologics and biosimilars. Part I: Biologics: what are they and where do they come from? Can Pharm J 2010;143:134-9.

29. Kozlowski S, Woodcock J, Midthun K, et al. Developing the nation's biosimilars program. N Engl J Med 2011;365:385-8.

30. Rademacher TW, Parekh RB, Dwek RA. Glycobiology. Annu Rev Biochem 1988:57:785-838.

31. Schellekens H. Bioequivalence and the immunogenicity of biopharmaceuticals. Nat Rev Drug Discov 2002;1:457-62.

32. European Medicines Agency. Guideline on similar biological medicinal products containing biotechnology-derived proteins as active substance: non-clinical and clinical issues. 2006. http://www.ema.europa.eu/docs/en_GB/document_library/ Scientific guideline/2009/09/WC500003953.pdf (accessèd 11 Apr 2012).

33. US Food and Drug Administration. Scientific considerations in demonstrating biosimilarity to a reference product: draft guidance February 2012. http://www.fda. gov/downloads/Drugs/GuidanceComplianceRegulatorylnformation/Guidances/ UCM291128.pdf (accessed 4 Apr 2012).

34. Shealy D, Cai A, Staquet K, et al. Characterization of golimumab, a human monoclonal antibody specific for human tumor necrosis factor alpha. MAbs 2010;2:428-39.

35. US Food and Drug Administration. Prescribing information for adalimumab. http:// www.accessdata.fda.gov/drugsatfda docs/label/2011/125057s0276lbl.pdf (accessed 10 Aug 2012).

36. Chung $\mathbf{C H}$, Mirakhur $\mathrm{B}$, Chan $\mathrm{E}$, et al. Cetuximab-induced anaphylaxis and $\lg \mathrm{E}$ specific for galactose-alpha-1,3-galactose. N Engl J Med 2008;358:1109-17.

37. Kessler M, Goldsmith D, Schellekens H. Immunogenicity of biopharmaceuticals. Nephrol Dial Transplant 2006;21(Suppl 5):v9-12.

38. Baert $\mathbf{F}$, Noman $\mathrm{M}$, Vermeire $\mathrm{S}$, et al. Influence of immunogenicity on the long-term efficacy of infliximab in Crohn's disease. N Engl J Med 2003;348:601-8.

39. Korswagen LA, Bartelds GM, Krieckaert CL, et al. Venous and arterial thromboembolic events in adalimumab-treated patients with antiadalimumab antibodies: a case series and cohort study. Arthritis Rheum 2011;63:877-83.
40. Doyle MK, Cuellar ML. Drug-induced vasculitis. Expert Opin Drug Saf 2003;2:401-9

41. Ramos-Casals M, Perez-Alvarez R, Perez-de-Lis M, et al. Pulmonary disorders induced by monoclonal antibodies in patients with rheumatologic autoimmune diseases. Am J Med 2011:124:386-94.

42. Finckh A, Simard JF, Gabay C, et al. Evidence for differential acquired drug resistance to anti-tumour necrosis factor agents in rheumatoid arthritis. Ann Rheum Dis 2006;65:746-52.

43. Radstake TR, Svenson M, Eijsbouts AM, et al. Formation of antibodies against infliximab and adalimumab strongly correlates with functional drug levels and clinical responses in rheumatoid arthritis. Ann Rheum Dis 2009;68:1739-45.

44. Wolbink GJ, Vis M, Lems W, et al. Development of antiinfliximab antibodies and relationship to clinical response in patients with rheumatoid arthritis. Arthritis Rheum 2006;54:711-15.

45. Krapp S, Mimura Y, Jefferis R, et al. Structural analysis of human IgG-Fc glycoforms reveals a correlation between glycosylation and structural integrity. J Mol Biol 2003;325:979-89.

46. Isaacs JD, Greenwood J, Waldmann H. Therapy with monoclonal antibodies. II. The contribution of Fc gamma receptor binding and the influence of $\mathrm{C}(\mathrm{H}) 1$ and $\mathrm{C}(\mathrm{H}) 3$ domains on in vivo effector function. $J$ Immunol 1998;161:3862-9.

47. Mitoma H, Horiuchi T, Tsukamoto $\mathrm{H}$, et al. Mechanisms for cytotoxic effects of anti-tumor necrosis factor agents on transmembrane tumor necrosis factor alpha-expressing cells: comparison among infliximab, etanercept, and adalimumab. Arthritis Rheum 2008;58:1248-57.

48. Canete JD, Suarez B, Hernandez MV, et al. Influence of variants of Fc gamma receptors IIA and IIIA on the American College of Rheumatology and European League Against Rheumatism responses to anti-tumour necrosis factor alpha therapy in rheumatoid arthritis. Ann Rheum Dis 2009;68:1547-52.

49. Ramirez J, Fernandez-Sueiro JL, Lopez-Mejias R, et al. FCGR2A/CD32A and FCGR3A/CD16A variants and EULAR response to tumor necrosis factor-alpha blockers in psoriatic arthritis: a longitudinal study with 6 months of followup. $J$ Rheumatol 2012:39:1035-41.

50. McCamish M, Woollett G. The state of the art in the development of biosimilars Clin Pharmacol Ther 2012:91:405-17.

51. European Medicines Agency. BWP report to the CHMP: beta-interferons and neutralising antibodies (in multiple sclerosis). 1st phase of the project: Development of a standardised assay methodology for the determination of neutralising antibodies. 2008. http://www.ema.europa.eu/docs/en GB/document library/Report/ 2009/11/WC500015395.pdf (accessed 12 Jun 2012).

52. European Medicines Agency. Guideline on similar biological medicinal products. 2005. http://www.ema.europa.eu/ema/index.jsp?curl=pages/includes/document/ document_detail.jsp?webContentld=WC500003517qmid=WC0b01ac058009a3dc (accessed 11 Apr 2012).

53. European Medicines Agency. Guideline on similar biological medicinal products containing monoclonal antibodies-non-clinical and clinical issues. 2012. http:// www.ema.europa.eu/docs/en_GB/document_library/Scientific_guideline/2012/06/ WC500128686.pdf (accessed 3 Jul 2012).

54. US Food and Drug Administration. Guidance for Industry. Biosimilars: Questions and Answers Regarding Implementation of the Biologics Price Competition and Innovation Act of 2009. http://www.fda.gov/downloads/Drugs/.../Guidances/ UCM273001.pdf (accessed 4 Apr 2012)

55. Biologics Price Competition and Innovation Act, 2009. http://www.fda.gov/ downloads/Drugs/GuidanceComplianceRegulatoryInformation/UCM216146.pdf (accessed 12 Nov 2012).

56. Lee H, Yim DS, Zhou H, et al. Evidence of effectiveness: how much can we extrapolate from existing studies? AAPS J 2005;7:E467-74.

57. Mellstedt H, Niederwieser D, Ludwig H. The challenge of biosimilars. Ann Oncol 2008;19:411-19.

58. Blackstone EA, Fuhr JP Jr. Innovation and competition: will biosimilars succeed? Biotechnol Healthc 2012;9:24-7.

59. Simoens S. Biosimilar medicines and cost-effectiveness. Clinicoecon Outcomes Res 2011;3:29-36.

60. Biosimilar news. Pfizer starts biosimilar rituximab Phase $1 / / /$ trial. http://www. biosimilarnews.com/pfizer-starts-biosimilar-rituximab-phase-iii-trial(accessed 8 Nov 2012).

61. ClinicalTrials.gov. A Pharmacokinetic/Pharmacodynamic Study Comparing PF-05280586 To Rituximab In Subjects With Active Rheumatoid Arthritis With An Inadequate Response To TNF Inhibitors (REFLECTIONS B328-01). http://www. clinicaltrials.gov/ct2/show/NCT01526057?term =PF-05280586\&rank=1 (accessed 8 Nov 2012).

62. GalB online. Sandoz announces biosimilar rituximab. http://www.gabionline.net/ Biosimilars/News/Sandoz-announces-biosimilar-rituximab (accessed 8 Nov 2012).

63. ClinicalTrials.gov. GP2013 in the Treatment of RA Patients Refractory to or Intolerant of Standard Therapy. http://www.clinicaltrials.gov/ct2/show/NCT01274182? term $=$ GP2013 rrank $=1$ (accessed 8 Nov 2012). 